\title{
TAXATION: LEGISLATIVE EXPENDITURES NOT DEDUCTIBLE AS BUSINESS EXPENSES
}

$I_{\mathrm{N}}$ Cammarano v. United States, and F. Strauss E Son, Inc. v. Commisssioner, ${ }^{1}$ the Supreme Court held that the taxpayers could not deduct the expenses incurred in opposing the passage of legislation which would have destroyed their businesses. ${ }^{2}$ The taxpayers, through trade organizations, ${ }^{3}$ had helped defeat initiatives submitted to the electorate. ${ }^{4}$ The Court rejected the contention that such expenses were ordinary and necessary business expenses and held that the ambiguous "ordinary and necessary" test could be implemented by a Treasury Regulation:"

Sums of money expended for lobbying expenses, the promotion or defeat of legislation, the exploitation of propaganda, including advertising other than

1358 U.S. 498 (1959).

"The taxpayers claimed that these expenses were "ordinary and necessary" business expenses under INT. Rev. CODE of 1939, ch. 2, § 23 (a) (I)(A), 53 Stat. I (now INr. REV. CODE OF 1954, $\$ 162(\mathrm{a}))$.

- In Cammarano *. Utrited: States, the petitioners had an interest in a partnership - which was a member of the Washington Beer. Wholesalers Association. The Association had established a trust fund for the deposit of funds collected from its members. In the Strauss case, the petitioner, with eight other Arkansas liquor. wholesalers, organized Arkansas Iegal Control Associates, Inc., which collected contributions from its members.

- Expenditures were made in the Cammarano case to defeat a measure submitted to the electorate which, if passed, would have placed the sale of beer and wine in the hands of the state. In the Strauss case, the proposed mitiative called for statewide prohibition. Influence was exerted in each case by means of advertising and other forms of publicity. The petitioners attempted to distinguish expenses incurred in attempting to promote or defeat measures before legislatures from expenses incurred to influence measures submitted directly to the electorate. In rejecting this distinction the court said: "We think that initiatives are plainly 'legislation' within the meaning of these Regulations. Had the measures involved in these cases been passed by the people of Washington and Arkansas 'they would have had the effect and status of ordinary laws in every respect. The Constitutions of the States of Washington and Arkansas both explicilly recognize that in providing for initiatives they are vesting legislative power in the people." 358 U.S. at 505 .

"Treas. Reg. III, § 39.23 (0)-1 (1943) ("Contributions or Gifts by Individuals") was applied in Cammaratzo, and Treas. Reg. 11 1 , $\$ 39.23$ (g) -t (1943) ("Contributions or Gifts by Corporations") was applied in the Strauss case. These regulations were written pursuant to INT. REv. CODE OF $1939 \mathrm{ch}, 2, \S \S 23(0)(2)$ and $23(\mathrm{~g})(2)$, 53 State. 1, which, in limiting deductibility of charitable contributions, specifically exclude gifts to organizations a substantial part of whose activities is the carrying on of. propaganda or otherwise attempting to influence legislation. 'The regulations, the' wording of which is exactly the same, are consolidated in regulations under the rg54 Code in Treas. Reg. $\$$ 1.162-15, 
trade advertising, and contributions for campaign expenses, are not deductible from gross income.

Although this regulation was originally intended to apply only to the deductibility of charitable contributions, it frequently has been invoked in the context of business expenses. ${ }^{8}$ In the landmark decision of Textile Mills Sec. Corp. v. Commissioner, ${ }^{7}$ the Supreme Court applied this regulation to disallow the deduction of a lobbying expense as a business expense. ${ }^{8}$ Although the Court distinguished legitimate business expenses from legislative expenditures which might contravene public policy, ${ }^{9}$ it adopted the entire regulation. ${ }^{10}$ Because of this apparent inconsistency, it is difficult to delineate the precise holding of the Textile Mills case. ${ }^{11}$ Conceivably, some of the expenditures enumerated in the regulation might qualify as legitimate business expenses. ${ }^{12}$

${ }^{\circ}$ See, e.g., Revere Racing Ass'n v. Scanlon, 232 F.2d 816 (Ist Cir. 1956); American Hardware \& Equip. Co. v. Commissioner, 202 F.2d 126 (4th Cir.), cert. denied, 346 U.S. 814 (1953); Harden Mortgage Loan Co. v. Commissioner, 137 F.2d 282 (10th Cir. 1943); Herbert Davis, 26 T.C. 297 (1952), rew'd on other grounds, 217 F.2d 329 (9th Cir. 1954).

314 U.S. 326 (1941).

"In discussing the history of the regulation, the Court said: "The ban against deductions of amounts spent for 'lobbying' as 'ordinary and necessary' expenses of a corporation derived from a Treasury Decision in 1915." Textile Mills Sec. Corp. v. Commissioner, supra note 7 , at 337 . This reference is to T.D. 2137,17 TREAS. DEC. INT. REv. 48, 57-58 (1915): "Sums of money expended for lobbying purposes and contributions for campaign expenses are held not be an ordinary and necessary expense in the operation and maintenance of the business of a corporation, and are therefore not deductible from gross income in arriving at the net income upon which the income tax is computed."

${ }^{\circ}$ "Contracts to spread such insidious influences through legislative halls have long been condemned. . . . There is no reason why, in the absence of clear Congressional action to the contrary, the rule-inaking authority cannot employ that general policy in drawing a line between legitimate business expenses and those arising from that family of contracts to which the law has given no sanction." 314 U.S. at 338-39.

10 "Petitioner's argument that the regulation is invalid likewise lacks substance. The words 'ordinary and necessary' are not so clear and unambiguous in their meaning and application as to leave no room for an interpretative regulation. The numerous cases which have come to this Court on that issue bear witness to that. . . . Nor has the administrative agency usurped the legislative function by carving out this special group of expenses and making them nondeductible." Id. at 338 .

${ }^{22}$ Cases citing Textile Mills, however, often limit interpretation of its holding to the denial of the deduction because of "lobbying" and do not apply it to the broader concept of "influence of legislation." See, e.g., Lilly.v. Commissioner, 343 U.S. 90, 95 (1952); Commissioner v. Heininger, 320 U.S. 467,473 (1943); American Hardware \& Equip. Co. v. Commissioner, 202 F.2d 126 (4th Cir. 1953); Harden Mortgage Loan Co. v. Commissioner, 137 F.2d 282 (roth Cir. 1943).

${ }^{23}$ All contracts for the influence of legislation have not been condemned. These 
In two subsequent decisions, the Tax Court distinguished between lobbying and other forms of legislative expenditures. In McClintockTrunkey Co. v. Commissioner, ${ }^{13}$ the entire deduction was disallowed because the taxpayer could not determine what portion of the expenditures was not lobbying expenses. ${ }^{14}$ In Luther Ely Smith v. Commissioner, ${ }^{15}$ which involved a factual situation strikingly similar to that in the Cammarano case, the Tax Court allowed the deduction of payments made to an institute to help enact a state constitutional amendment and noted that no lobbying expenditures were made to the legislature. ${ }^{16}$

The scope of the problem is much greater, however, than a simple distinction between lobbying expenses and non-lobbying expenses would indicate.

The regulation invoked in the instant cases may be quite appropriate when applied to charitable contributions, for, by their very nature, certain institutions engaged in legislative activity have never been appropriate objects of bona fide charitable contributions. ${ }^{17}$ But regardless of the applicability of the regulation to charitable contributions, the tests for determining deductible business expenses traditionally have turned on entirely different factors-the purpose of an expenditure and its relation to the particular business. ${ }^{18}$ Congress purposely worded the

agreements which seek open and legitimate presentation of facts are legitimate. Steele v. Drummond, 275 U.S. 199 (1927).

${ }^{13} 19$ T.C. 297 (1952), rewd on other grounds, 217 F.2d 329 (9th Cir. 1954).

${ }^{16}$ The Tax Court denied a deduction for contributions to three organizations including the Beer Association involved in Cammarano. Two of these organizations clearly fostered legislation, having a direct contact with the legislature. The beer association, as in the Cammarano case, expressed disapproval of proposed "dry" legislation. Because the taxpayer anade the contribution as a single expenditure, being unable to show how much was not for lobbying, the Tax Court found that "a substantial part of the activities of the organizations ... . was devoted to lobbying purposes, the promotion or defeat of legislation, and the exploitation of propaganda." "Id. at 304 .

${ }_{3}^{25}$ T.C. 696 (1944), acq., 1944 CUM. BULL. 26. But acquiescence was withdrawn by Rev. Rul. 58-255, 1958 INT. Rev. Bull. No. 21, at 16. The withdrawal coincided with the granting of certiorari in the Cammarano case.

${ }^{16}$ The taxpayer, a lawyer, contributed to an organization formed to amend the Constitution of Missouri by providing that candidates for admission to judicial office be nominated by a commission. The amendment was adopted, and as a self-operative provision, became law. Here the taxpayer's "business" was not under a threat of imminent destruction; he had only shown that his trial practice suffered because of a growing disrespect for the judicial system as it existed. The same regulation involved in Cammarano was found inapplicable, and Textile Mills was not even inentioned.

${ }^{17}$ For illustrations of nonallowable contributions for partisan or controversial propaganda, see 5 Mertens, Federal Income TAXation § 31.26 (1956).

${ }^{28}$ The fundamental requirements of the deductibility of business expenses, "trade or business" and "ordinary and necessary," are discussed in 4 MERTENs, op. cit. supra note $17, \S \S 25.08,25.09$ (1954). 
business expenses section to embrace all forms of expenditures, ${ }^{19}$ and it seems contrary to the manifest purpose of this section to entertain a blanket prohibition against a certain form of expenditure. Charitable contributions deductions and business expenses deductons, being fundamentally different in nature and purpose, should be implemented by separate and distinct regulations.

The inequity of the instant decisions is most obvious when applied to a business which is peculiarly dependent upon the existence of favorable legislation. Thus, in the Cammarano case, the taxpayers' business would have been destroyed if the electorate had voted to abolish the existing methods of liquor distribution. Under the present application of the regulation, however, the effect upon a taxpayer's business would be totally immaterial.

The Supreme Court has rejected this argument and has pointed out that the regulations constitute sharply defined public policy under the oft-quoted Heininger case. ${ }^{20}$ But this rule begs the question because it would apply with equal force to any Treasury regulation. Rather, the substantial purpose embodied in a regulation would seem to be the policy to be applied by the courts. As to business expenses, the essential purpose of the regulation is to prevent the Treasury's underwriting the political activities of business. ${ }^{21}$ Unfortunately, the language of this regulation does not limit it to preventing the attainment of political objectives at the Government's expense. Yet the policy of making expenditures carefully calculated to prevent the economic extermination of a business entity appears to merit judicial sanction..$^{22}$ At the least, cases should be decided on an ad hoc basis in this sensitive policy area.

${ }^{10}$ See Alexandria Gravel Co. v. Commissioner, 95 F.2d 615 (5th Cir. 1938).

${ }^{20}$ Commissioner v. Heininger, 320 U.S. 467 (1943). In Cammarano the petitioners used this case in support of their argument that sums spent for preservation of business from destruction are deductible. The Court, however, used the case to open the policy argument.

${ }_{21} E . g .$, "[E]xpenditures incurred for newspaper or magazine advertisements or radio or television programs urging voters to vote for a particular candidate for political office will be treated by the Commissioner as nondeductible contributions for political campaign expenditures." 4 MERTENS, op. cit. supra note $17, \S 25.38$. (1954).

${ }_{22}$ When the destruction of a taxpayer's business is imminent the cases uniformly allow deductions on the ground that there is such a direct connection with the life of the business. Los Angeles \& S.L.R.R., is B.T.A. 168 (1929), involving a publicity campaign to create a favorable public opinion and avert enactment of unfavorable or injurious legislation for the railroads, represents the leading case in this area. The Board in allowing the deduction cited as authority, G. T. Wofford, 15 B.T.A. 1225 (1929), aff'd, 49 F.2d 1027 (5th Cir. 1931); George Ringler \& Co., 10 B.T.A. $1 \times 34$ (1928); Independent Brewing Co. v. Coinmissioner, 4 B.T.A. 370 (1926). The Los Angeles case has been followed in other Tax Court cases involving the same railroad 
Actually, the underwriting of objectionable political activities ${ }^{23}$ could be avoided by application of the Heininger ${ }^{24}$ and Lilly ${ }^{25}$ decisions to business expense deductions. These cases interpreted the inhibiting effects of public policy considerations upon the deductibility of business expenses to be properly limited to controversies involving sharply defined policies laid down in statutes and judicial decisions. ${ }^{28}$ Within these bounds, it is evident that there are numerous statutes proscribing the types of political activity which the Treasury would be disinclined to subsidize. ${ }^{27}$

The ramifications of the Cammarano case are far-reaching. If the decision stands as precedent, corporations will bear the burden of all payments made to thwart the passage of any form of legislation which would contravene their business interests. Certain industries, such as the liquor, cigarette, and trucking businesses, which are peculiarly vulnerable to legislative enactments, will suffer a substantial adverse effect. Moreover, it seems grossly unfair to penalize a taxpayer for openly and legitimately protecting itself from potential economic loss or extermination.

Furthermore, if Cammarano and McClintock-Trunkey ${ }^{28}$ are fol-

association. Texas \& Pac. Ry., 9 B.T.A. 365 (1927); Western Maryland Ry., 12 B.T.A. 889 (1928). See also All States Freight, Inc. v. United States, 72 F. Supp. 673 (N.D. Ohio 1947) (deduction allowed of expenses incurred where existence of business threatened in hearings before administrative boards).

${ }^{28}$ Of the various activities engaged in to influence the passage of legislation, only certain categories are against public policy. These are the obtaining of legislative action "as a matter of favor by means of personal influence, solicitation, and the like, or by other improper or corrupt means." Steele v. Druminond, 275 U.S. 199, 206 $(1927)$.

${ }_{24}$ Note 20 supra.

${ }^{25}$ Lilly v. Commissioner, 343 V.S. 90 (1952).

${ }^{20}$ Actually the Heininger case, followed in the Lilly case, lays down two standards for determining deductibility: ( $x$ ) consideration of the "ways of conduct and the forms of speech prevailing in the business world," and (2) in order to disallow the expense there inust be frustration of a "sharply defined national or state policy proscribing particular types of conduct." 320 U.S. at 472-473. The distinction is emphasized by two recent cases: in one, penalties paid by truckers for violations of state law, even though the violations were unintended, are not deductible as a business expense, Tank Truck Rentals Inc. v. Commissioner, 356 V.S. 30 (1957), while in the other, rents and salaries which would certainly be deductible in lawful enterprise are not disallowed because incurred in an unlawful business on the theory that "sharply defined national policy" does not operate to make an illegal enterprise pay taxes on gross receipts in the absence of: a clear expression of Congressional intent, Commissioner v. Sullivan, 356 U.S. 27 (.1957).

.. See also 4 MERTENS, op. cit. supra note $17, \S 25.131$ (1954).

$\therefore{ }^{27}$ See PaUt, Taxation in the United States 695 (1954).

${ }^{28}$ See notes 13 \& 14 supra. 
lowed, payments made through legitimate trade organizations will fall under the broad swath of this holding if eventually appropriated for legislative influence. And if the taxpayer cannot show to the Treasury's satisfaction what portion of his dues was ultimately appropriated to this purpose, then the entire amount will be disallowed. ${ }^{29}$ Thus, the Treasury has maneuvered itself into an indefensible position through blind adherence to a regulation not originally intended by the Treasury to apply to business expenses and worded so broadly as to preclude distinction between taxpayers of individual circumstances.

${ }^{20}$ The Tax Court has already applied the Cammarano case in Thomas J. Barkett, 31 T.C. No. 114 (1959). Assessments paid by a retail liquor store to a trade association were held not deductible. The general purpose of the association was to promote good standards of conduct among members, but the Tax Court also found some activity to influence the general public. The taxpayer claimed he joined in order to participate in the prevention of business practices which had an adverse effect on his business, but the Tax Court applied Cammarano because he could not show how much of the funds given to the association was used for carrying on propaganda and influencing legislation. 